НАУКИ О ЗЕМЛЕ

"НАУКА. ИННОВАЦИИ. ТЕХНОЛОГИИ", № 2, 2019

25.00 .23

УДК 911.6

ФИЗИЧЕСКАЯ ГЕОГРАФИЯ И БИОГЕОГРАФИЯ, ГЕОГРАФИЯ ПОЧВ

И ГЕОХИМИЯ ЛАНДШАФТОВ

Проскурин В.С. 000 «Картфонд», г. Ставрополь, Россия. stavr.pro@mail.ru

\title{
ЛАНДШАФТНО-РЕКРЕАЦИОННЫЙ ПОТЕНЦИАЛ ТЕРРИТОРИИ КАВКАЗСКИХ МИНЕРАЛЬНЫХ ВОД ДЛЯ РАЗВИТИЯ ТУРИЗМА
}

Введение:

Район КМВ обладает разнообразным ландшафтно-рекреационным потенциалом для развития лечебной, горно-спортивной и туристско-экскурсионной деятельности. В качестве общеметодологической базы в обосновании зонирования территории для различных видов туризма, оценки социально-экономических функций, отражающих степень возможного участия ландшафта в удовлетворении рекреационных потребностей общества, выступает ландшафтный подход. Результаты исследования позволяют выделить участки потенциального развития отдельных видов туризма с учетом их интегральной оценки.

Материалы и методы: Комплексная оценка ландшафтно-рекреационного потенциала территории, включает в себя анализ компонентов ландшафта: рельефа, климата, гидрографии и биоты ландшафта. Методика выявления зон с наибольшим ландшафтно-рекреационным потенциалом подразумевает построение гексагональных операторов со стороной 5 км и расчет в полигонах (ячейках) отобранных показателей в геоинформационной системе QGIS После расчёта для каждого полигона проводилась классификация компонентов по 5-бальной шкале на основе алгоритма естественных границ Дженкенса. Алгоритм подразумевает естественную группировку данных. Границы классов определяются таким образом, чтобы сгруппировать схожие значения и максимально увеличить различия между классами для визуального выявления зон.

Результаты

исследований и обсуждения: Главный результат работы - комплексная оценка компонентов групп ландшафтов применительно к различным направлениям туризма. Данная оценка позволяет провести зонирование территории. При этом важно, что для каждого вида туризма учитывался компонент ландшаста с наибольшим весом. Результаты исследования применялись при разработке генерального плана городского округа города-курорта Кисловодска, и в дальнейшем могут быть применены при разработке документов стратегического и территориального планирования.

Выводы: $\quad$ Проведенное ландшафтно-рекреационное зонирование позволяет выделить группы ландшафтов с наибольшим потенциалом для отдельных видов туризма. Так, для экстремального туризма наиболее перспективной зоной развития является культурно-природный ландшафт куэстовых хребтов, а также локальные участки ландшафрта аллювиальных террасированных долин. Наибольшие показатели для развития экологического туризма были получены для ландшафтов предгорий остепненных лугов и луговых степей. Наименее благоприятными являются ландшафты эрозионо-аккумулятивных равнин. Данный комплексный и стратегический подход показывает территории с наибольшим потенциалом развития.

Ключевые слова: ландшафт, ландшафтно-рекреационный потенциал, природно-территориальный комплекс, зонирование, районирование, территориальное планирование, аттрактивность, ГИС. 
Proskurin V.S.

000 «Kartfond», Stavropol, Russia

stavr.pro@mail.ru

\section{LANDSCAPE AND RECREATIONAL CAPACITY OF THE TERRITORY OF CAUCASUS MINERALNYE VODY REGION FOR TOURISM DEVELOPMENT}

Introduction:

Materials

and methods:

Results of researches and discussion:

Conclusions:

Keywords:
The Region of Caucasus Mineralnye Vody region has the various landscape and recreational potential for development of medical, mountain and sports and tourist and excursion activity. A basis of a research is landscape approach which acts as all-methodological base in justification of zoning of the territory for different types of tourism, assessment of with-tsilno-economic functions reflecting extent of possible participation of a landscape in satisfaction of recreational requirements of society. Results of a research allow to distinguish sites of potential development of separate types of tourism taking into account integrated assessment.

complex assessment of landscape and recreational capacity of the territory, includes the analysis of components of a landscape: relief and raschlenennost of the territory, climate, hydrography, landscape biotics. The technique of identification of zones with the largest landscape and recreational potential for development of tourism means creation of hexagonal operators with the party of 5 $\mathrm{km}$ and calculation in grounds (cells) of the selected indicators in QGIS geographic information system. After calculation for each ground classification of components by a 5-ball scale on the basis of an algorithm of natural borders Dzhenkens was carried out. The algorithm means natural group of data. Borders of classes are defined so that to group similar values and as much as possible to increase differences between classes for visual identification of zones.

The main result of work - complex assessment of components of a landscape in relation to various directions of tourism. This assessment allows to carry out zoning of the territory according to the obtained data. At the same time it is important that for each type of tourism the defining value was accepted by that component of a landscape which has the largest weight. Results of a research are used when developing the master plan of the city district of the resort town of Kislovodsk, and further can be used when developing documents of strategic and territorial planning.

The received landscape and recreational zoning allows to allocate landscapes with the largest potential for separate types of tourism. So, for extreme tourism the most perspective zone of development is the cultural and natural landscape the kuestovykh of ridges and also local sites of a landscape alluvial the terrasirovannykh of valleys. The greatest indicators for development of ecological tourism were received by the area in the west of the foothills the ostepnennykh of meadows and meadow steppes. The least favorable for development of all presented types of tourism landscapes the degressionnykh of the opened lands and also landscapes of eroziono-accumulative plains possess. This integrated and strategic approach shows territories with the largest potential of development.

landscape, landscape and recreational potential, natural and territorial complex, zoning, division into districts, territorial planning, attraktivnost, GIS. 


\section{Введение}

Кавказские Минеральные Воды (КМВ) являются одной из наиболее перспективных территорий для развития туризма Северо-Кавказского макрорегиона. Туризм, как вид хозяйственной деятельности человека, использует как весь интегральный потенциал ландшафтов, так и его отдельных компонентов. Методологической основой исследования стал ландшафтный подход, позволяющий территориально и комплексно оценить рекреационный потенциал уникальных природных ландшафтов региона КМВ. Такой подход в изучении туризма стал активно использоваться в начале 70$\mathrm{x}$ годов прошлого столетия, в рамах формировавшейся в этот период отечественной рекреационной географии. Появляется понятие социально-экономических функций ландшафта, призванное оценить удовлетворение ландшафтом некоторых потребностей общества. В рекреационной географии обращают внимание на основные социально-экономические функции ландшафта, формирующие его рекреационный потенциал: ресурсовоспроизводящие, средовоспроизводящие и природоохранные [9]. Результаты подобных исследований региона КМВ получили отражение в научных сборниках, изданных в 1970-80-х гг, а также в монографии «Рекреационные ресурсы Северного Кавказа». Таким образом, ландшафтно-рекреационный потенциал должен отражать меру возможного выполнения ландшафтом социальноэкономических функций, как совокупности природных ресурсов и условий, оказывающих положительное влияние на человеческий организм путем сочетания физических и психических факторов восстановления работоспособности человека.

Ландшафтно-рекреационный потенциал КМВ изучался нами на основе схемы ландшафтов Северного Кавказа, приведенной в монографии В.А. Шальнева [10] (рис. 1).

В пределах выделенных групп ландшафтов проводилась оценка ландшафтно-рекреационного потенциала (далее ЛРП), которая представляет собой интегральную оценку свойств (как положительных, так и отрицательных) ландшафта и экологического состояния природной среды. Данное понятие взаимосвязано с экологическим потенциалом ландшафта, представляющим собой совокупность природных условий, влияющих на жизнь людей и создающих специфическую местную среду обитания.

Важно учитывать способность ландшафта создавать условия необходимые для организации туристской деятельности и жизнедеятельности человека в целом. Настоящее исследование опирается на методики по оценке природно-рекреационного потенциала Е.Ю. Колбовского и М.В. Гудковских $[5,7]$.

При оценке ландшафтно-рекреационного потенциала региона КМВ необходимо было учитывать его современную территориальную структуру и 


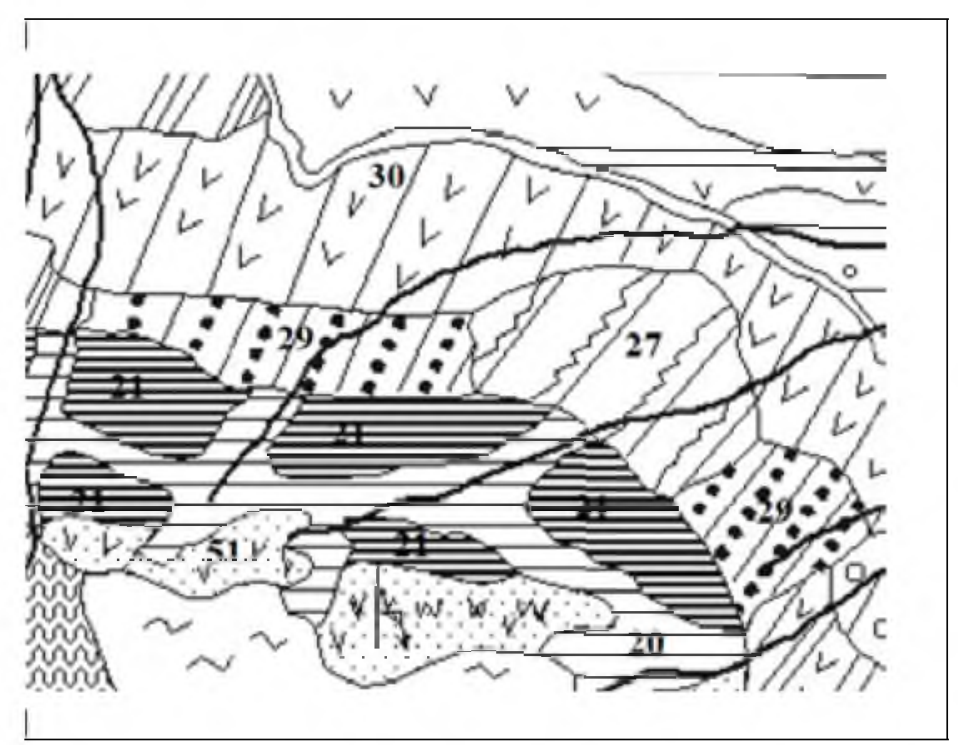

Рис. 1.

\section{Фрагмент ландшафтной карты района КМВ.}

Fig. 1. Kartoskhema fragment Landscapes of the North Caucasus.

Легенда: $\quad 20-\quad$ природно-культурные ландшафты поперечных речных долин и продольных эрозионно-тектонических депрессий в известняках, сланцах и песчаниках юры и мела, с лесостепями, остепненными лугами и горными степями на горных черноземах и аллювиальных почвах;

21 - культурно-природные ландшафты куэстовых хребтов, сложенных карбонатными породами и песчаниками мела и верхней юры, с остепненными горными лугами и участками горных степей на горных черноземах;

27 - природно-культурные ландшафты террасированных равнин, сложенных в основании моноклинально залегающими породами палеогена и неогена, с серией четвертичных и верхнеплиоценовых террас и развитием интрузивных форм новейшего вулканизма, с лесостепями предгорий (грабово-дубовыми и грабово-буковыми лесами и распаханными луговыми степями) на черноземах типичных и выщелоченных;

29 - природно-культурные ландшафты аллювиальных террасированных равнин предгорий, сложенных в основании моноклинально залегающими породами палеогена и неогена, с серией четвертичных и верхнеплиоценовых террас, с предгорными остепненными лугами и луговыми степями, полностью распаханными на выщелоченных и слабовыщелоченных черноземах;

30 - природно-культурные ландшафты аллювиальных террасированных равнин предгорий, сложенных в основании моноклинально залегающими породами палеогена и неогена, с серией четвертичных и верхнеплиоценовых террас, разнотравно-злаковыми степями, полностью распаханными, на черноземах обыкновенных малогумусных;

37 - природно-культурные ландшафты эрозионно-денудационных глубоко расчлененных высоких равнин и депрессий с обращенными формами рельефа, сложенных глинами майкопской серии, с распаханными ковыльно-типчаково-полынными и типчаково-полынными степями на черноземах обыкновенных остаточно-солонцеватых;

40 - сильно измененные природно-культурные ландшафты эрозионно-аккумулятивных и аллювиальных равнин, сложенных лессовидными суглинками, с полностью распаханными сухими степями на тёмно-каштановых и каштановых почвах. 
наличие ресурсов, которые могут быть привлечены к организации новых видов туристской деятельности. Это позволило провести зонирования наиболее перспективных территорий для развития различных видов туризма и рекреации, и осуществить территориальную привязку управленческих и планировочных решений. Использование геоинформационных моделей при расчетах ландшафтно-рекреационного потенциала изучаемого региона позволили провести описание, анализ и оценку каждого компонента выделенных групп ландшафтов, и выделение потенциальны зон развития туризма.

\section{Материалы и методы исследования}

В рамках оценки ЛРП разработана программа интегральной оценки ландшафтов для отдельных видов туризма. В методике исследования использовались новейшие методы оценки отдельных компонентов, важных для туристской деятельности. Поэтому интегральная оценка ландшафтно-рекреационного потенциала состоит из нескольких этапов:

Сбор и анализ данных который включает в себя физико-географическую характеристику исследуемой территории, анализ географического положения, доступности и т.д. Для создания пространственно-атрибутивной основы и базы данных использовались картографические материалы, данные спутниковых снимков, векторные слои GIS LAB, интерактивная карта ООПТ России, статистические данные по климату, лесам, реестр памятников природы. Была подготовлена картографическая основа ландшафтов района исследования. Интегральная оценка состоит из нескольких этапов:

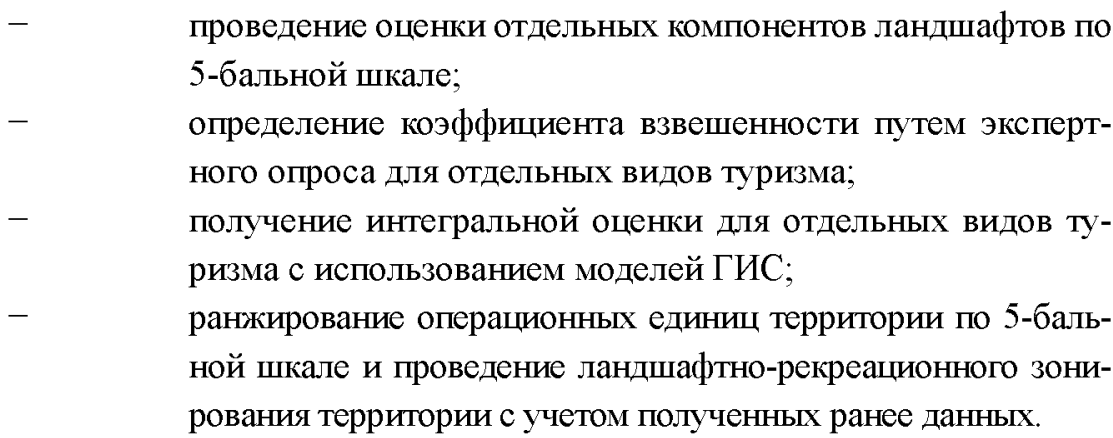

Важной особенностью оценки является учет специфики определенного вида туризма. Отдельные компоненты ландшафтов имеют разный вес при зонировании ландшафтов для отдельных видов туризма. Для этого, в рамках исследования был введен коэффициент взвешивания для каждого компонента ландшафта и оценки его влияния на конкретный вид туризма. Например, для экстремального туризма наиболее важным показателем яв- 
ляется рельеф местности, его расчлененность, высота над уровнем моря, крутизна и экспозиция склонов.

Механический перевод в баллы каждой группы показателей компонента ландшафта еще не создает условий для их интеграции, так как все они имеют разную ценность. Отсюда для корректировки факторов, влияющих на ландшафтно-рекреационный потенциал, в разрабатываемую методику была внедрена система взвешивания (табл. 1). Таким образом, каждый взвешенный показатель (В), выраженный в баллах, определялся по формуле

$$
\mathrm{B}=\mathrm{B} \times \mathrm{k} \text {, }
$$

где $\mathrm{k}-\quad$ коэффициент взвешивания [6].

Полученные результаты показаны в табл. 1.

Таблица 1. КОЭФФИЦИЕНТЫ ВЗВЕШИВАНИЯ КОМПОНЕНТОВ ЛАНДШАФТА ДЛЯ КАЖДОГО ИЗ ВИДОВ ТУРИЗМА

Table 1. Coefficients of weighing of components of a landscape for everyone from types of tourism

\begin{tabular}{|c|c|c|c|c|c|}
\hline \multirow{2}{*}{$\begin{array}{l}\text { Компонент } \\
\text { ландшафтта }\end{array}$} & \multirow[t]{2}{*}{ Оценочные показатели } & \multicolumn{4}{|c|}{ Вид туризма } \\
\hline & & $\begin{array}{l}\text { Экстрема- } \\
\text { льный }\end{array}$ & $\begin{array}{l}\text { Лечебно- } \\
\text { оздоровй- } \\
\text { тельный }\end{array}$ & $\begin{array}{l}\text { Экскурси- } \\
\text { онный }\end{array}$ & $\begin{array}{l}\text { Экологи- } \\
\text { ческий }\end{array}$ \\
\hline \multirow[t]{2}{*}{ Рельеф } & Расчлененность рельефа & 2,0 & 1,2 & 2,0 & 1,0 \\
\hline & Абсолютная высота & 2,0 & 0,5 & 1,0 & 1,0 \\
\hline \multirow[t]{4}{*}{ Биота } & Лесной покров & 0,1 & 1,0 & 1,0 & 2,0 \\
\hline & $\begin{array}{l}\text { Видовое разнообразие } \\
\text { растительности }\end{array}$ & 0,1 & 0,1 & 1,5 & 2,0 \\
\hline & Наличие ООПТ & 0,1 & 0,5 & 2,0 & 2,0 \\
\hline & $\begin{array}{l}\text { Количество памятников } \\
\text { природы (уникальные } \\
\text { ландшафтные формы) }\end{array}$ & 0,4 & 0,4 & 2,0 & 2,0 \\
\hline \multirow[t]{3}{*}{ Гидрология } & $\begin{array}{l}\text { Наличие озер, искусствен- } \\
\text { ных водоемов }\end{array}$ & 2,0 & 0,3 & 2,0 & 1,0 \\
\hline & Наличие рек & 2,0 & 0,3 & 1,0 & 2,0 \\
\hline & $\begin{array}{l}\text { Наличие пресных и } \\
\text { минеральных источников }\end{array}$ & 0,1 & 2,0 & 1,0 & 1,0 \\
\hline \multirow[t]{3}{*}{ Климат } & $\begin{array}{l}\text { Климатические показатели } \\
\text { (ветер) }\end{array}$ & 2,0 & 0,1 & 0,1 & 0,1 \\
\hline & $\begin{array}{l}\text { Климатические показатели } \\
\text { (осадки) }\end{array}$ & 0,1 & 0,1 & 0,1 & 0,1 \\
\hline & $\begin{array}{l}\text { Климатические показатели } \\
\text { (температура) }\end{array}$ & 1,5 & 2,0 & 2,0 & 2,0 \\
\hline
\end{tabular}


Для расчетов отдельных показателей и визуализации результатов исследования применялся способ картограмм. Методика выделения зон с различным ландшафтно-рекреационным потенциалом основана на выделении ячеек гексоганальных операторов со стороной 5 км, поскольку данное расстояние является оптимальным для прохождения пешеходных маршрутов разными возрастными категориями населения.

Расчет интегральных показателей для конкретного вида туризма и перевод его в баллы производился в геоинформационной системе QGIS по исходным цифровым слоям и созданным базам данных. Для каждого полигона (ячейки) была проведена автоматическая классификация каждого компонента (слоя) на 5 классов. Для классификации применялся алгоритм естественных границ Дженкинса, где классы основывались на естественной группировке данных. Объекты делятся на классы, границы которых устанавливаются там, где встречаются относительно большие различия между значениями данных. После этого был произведен автоматический перевод каждого класса в баллы от 1 до 5. Далее проводилось зонирование территории отдельных видов туризма с учетом интегральных видов оценки.

\section{Результаты исследования}

На основании проведенной оценки ландшафтно-рекреационного потенщиала региона КМВ проводилось покомпонентное зонирование территории и составлялась комплексная оценочная схема территории по совокупному сочетанию различных факторов, что позволило выявлять наиболее привлекательные территории для последующего развития туристской деятельности.

\section{Частные оценки.}

Зонирование территорий, по определению Алаева [1], представляет собой процесс, в ходе которого идентифицируются элементы пространства с различной интенсивностью какого-либо компонента, явления (в данном случае - абсолютные высоты, расчлененность), выявляется соответствие рассматриваемого элемента системы или объекта на основе сопоставления значений конкретных признаков. Данный процесс является частным случаем районирования, под которым понимается система территориального деления на районы разного типа и уровня в зависимости от поставленных целей и задач. Оценка компонентов и их значения для развития туризма была получена путем механического перевода элементов компонента в баллы по 5-ти бальной шкале: 


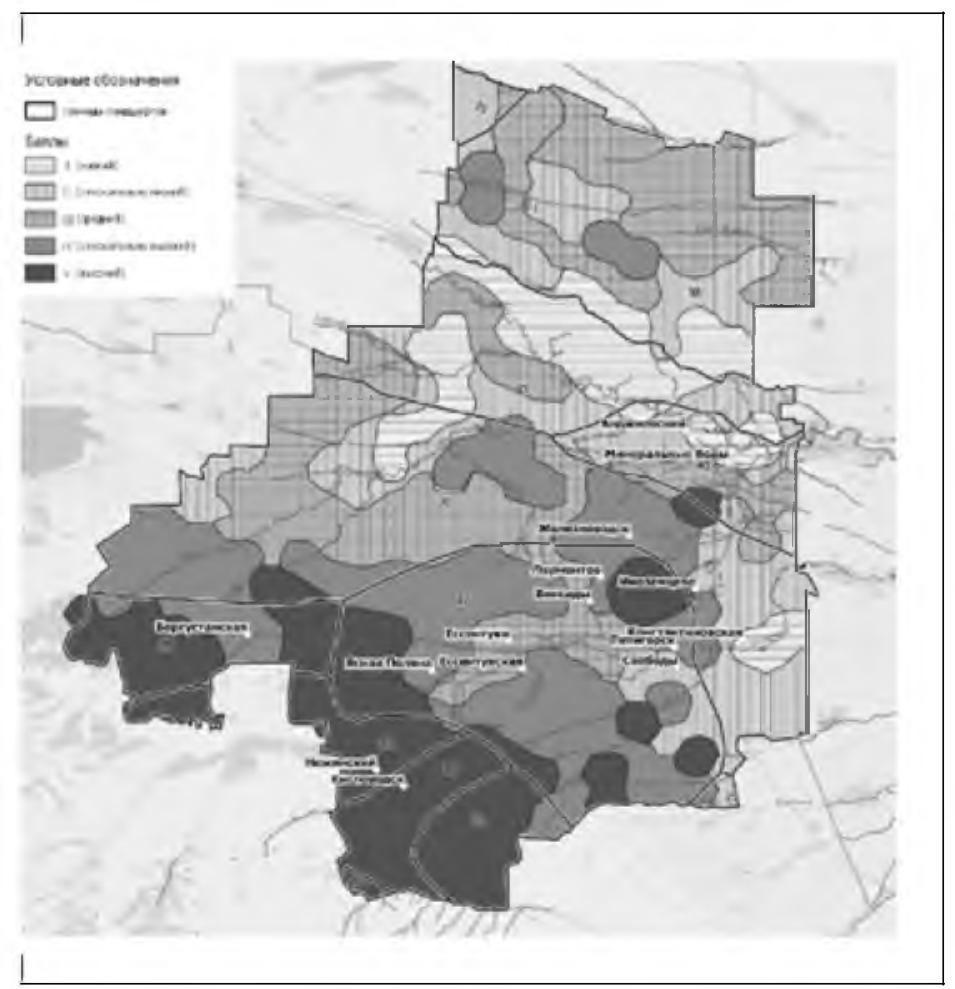

Рис. 2.

\section{Зонирование по компоненту «Рельеф».}

Fig. 2. Zoning on the Relief component.

1 балл - $\quad$ наиболее низкие показатели, для развития туризма;

2 балла - относительно низкие показатели;

3 балла - средние показатели, позволяющие говорить о развитии отдельных направлений туризма, как например, для лечебнооздоровительного;

4 балла - относительно высокий потенциал;

5 баллов - высокий потенциал. Определяющего развития многих форм туризма.

Таким образом было получено зонирование территории по всем компонентам ландшафта. Полученное зонирование проводилось в гранищах Предгорного муниципального района, и следующих городских округов: город Лермонтов, город-курорт Кисловодск, Пятигорск, Железноводск, 
Ессентуки, а также Минераловодский городской округ. В качестве примера приводится анализ данных одного из важнейших компонентов ландшафта рельефа (рис. 2).

Проведенное зонирование рельефа позволяет выделить области с высокими показателями. Выделенные участки характеризуется контрастным рельефом. Максимальные значение получил природно-культурный ландшафт поперечных речных долин и продольных эрозионно-тектонических депрессий (на рис. 2 №20), а также ландшафты куэстовых хребтов (№21). Наименьшее значение получила территория Кубано-Суркульской депрессии (№ 37 и 40). Высокие показатели имеют интрузивные формы в ландшафте 27 , имеющие локальные формы размещения.

\section{Общая оценка ландшафтно-рекреационного}

потенциала была получена путем суммирования баллов с учетом коэффициента взвешивания для каждой категории вида туризма. В соответствии с полученными данными было проведено зонирование территории для отдельных видов туризма. Большая часть ландшафтов, расположенных в указанным ранее территориальных образованиях имеют низкие показатели оценки (рис. 3).

Максимальное значение получил природно-культурный ландшафт поперечных речных долин и продольных эрозионно-тектонических депрессий (№20). Потенциал более 70 \% территории данного ландшафта оценивается в 5 баллов. Частично такое же значение получил ландшафты куэстовых хребтов. Здесь уже имеются области с меньшими значениями, но в целом эта территория оценивастся как с высоким и относительно высоким потенциалом. Небольшие островные участки высокого потенциала наблюдаются в ландшафтах наклонных террасированных долин, приуроченных к магматическим останцовым горам (№27 и №40). Участки средних значений расположены в ландшафтах предгорных аллювиальных террасированных равнин, а также на юго-западе ландшафтов разнотравных-западных степей. Наименьшие значения распространены в ландшафтах лесостепей предгорий и распаханных луговых степей с высокой степенью эродированности и распаханности. На выделенных участках с максимальными значениями целесообразно развивать следующие виды экстремального туризма: треккинг, парапланеризм, роупджампинг и другие.

Для лечебно-оздоровительного туризма наибольшие значение имеют участки, расположенные на северо-западе ландшафта террасированных равнин (№ 27), а также две небольшие области в ландшафтах низкогорий и предгорий Б. Кавказа, поперечных речных долин и продольно эрозионно-тектонических депрессий (№ 20). Это связано с расположением большой группы источников. Остальные ландшафты не представляют большой ценности в рамках развития лечебно-оздоровительного туризма (рис. 4). 


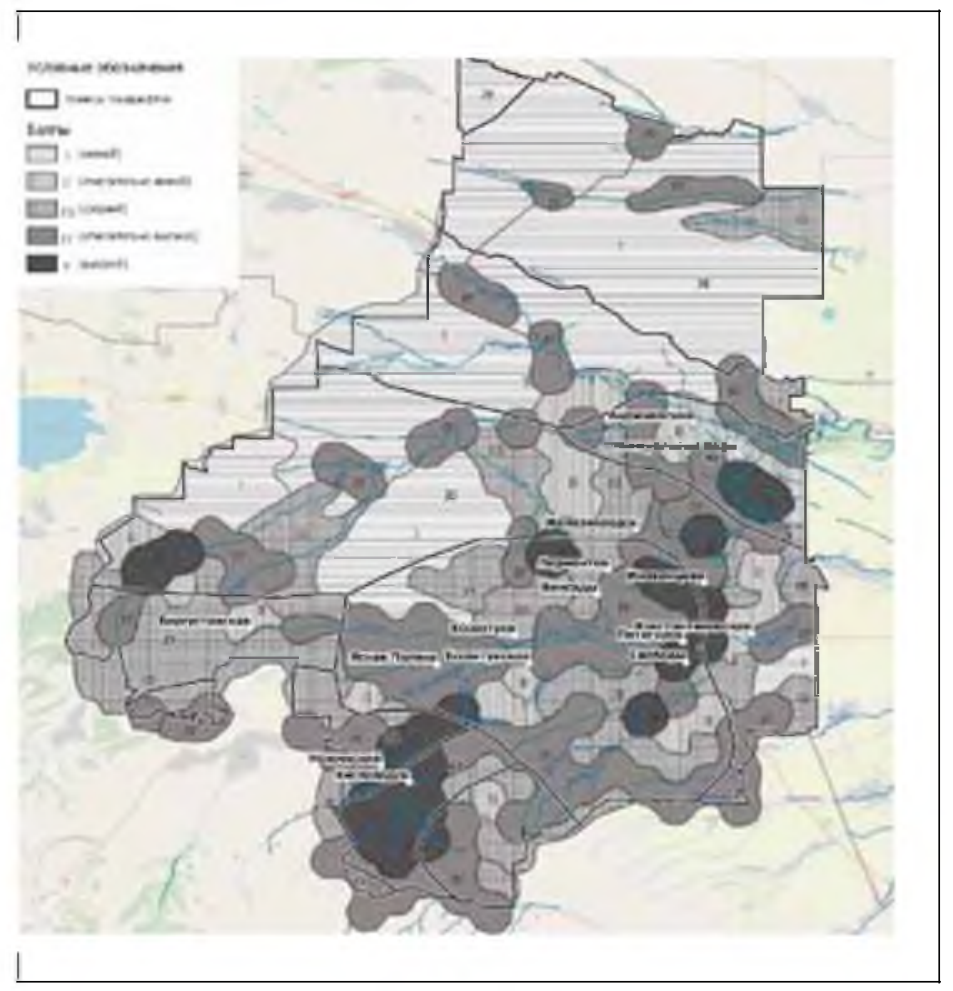

Рис. 3.

\section{Зонирование территории для экстремального туризма}

Fig. 3. Zoning of the territory for extreme tourism

Экологический туризм в большей степени связан с наличием ООПТ и лесных массивов. Максимальную оценку получили группы ландшафтов аллювиальньх террасированньх равнин предгорий, культурно-природные ландшафты куэстовых хребтов на границе с ландшафтами поперечных речных долин. Также имеется перспективная область на западе предгорий остепненных лугов и луговых степей. Наименее перспективные территории расположены в природно-культурных ландшафтах террасированньх долин предгорий и природно-культурные ландшафты эрозионно-денудационных глубоко расчлененных высоких равнин и депрессий (№30, 37) (рис. 5).

При проведении зонирования для экскурсионного туризма важными показателями являлись разнообразие групп ландшафтов, эстетичность, биологическое разнообразие. Заметную аттрактивность имеют участки, располо- 


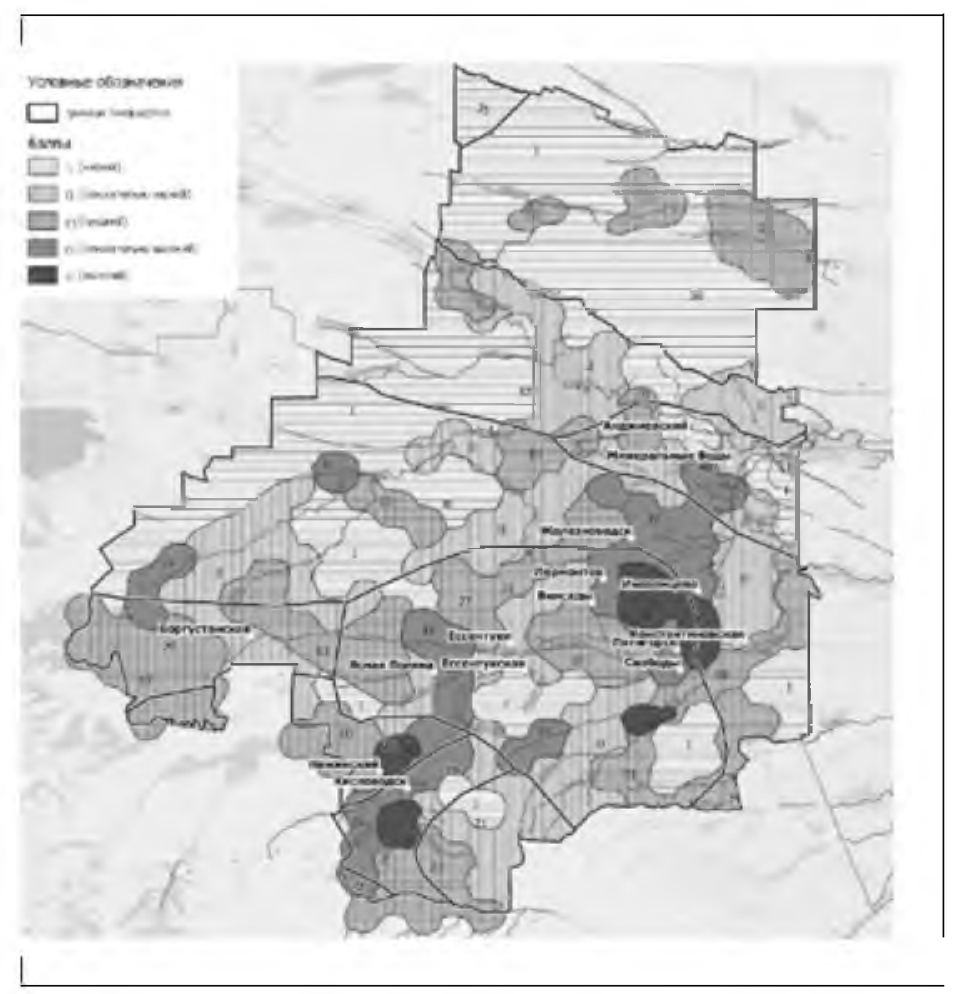

Pис. 4.

\section{Зонирование территории для лечебно-оздоровительного туризма.}

Fig. 4. Zoning of the territory for medical and improving tourism.

женные на территории ландшафтов куэстовый хребтов (20), ландшафтов террасированных равнин с развитием форм новейшего вулканизма и ландшафта аллювиальных террасированных равнин предгорий (27). Здесь наблюдается сосредоточение на небольшой области большого числа объектов природы, флористическое разнообразие, которое дополняется наличием разнообразных форм рельефа. Итогом является высокая степень аттрактивности мест перечисленных выше групп ландшафтов (рис. 6).

Средние значения получили природно-культурные ландшафты террасированных равнин и природно-культурные ландшафты аллювиальных террасированных равнин предгорий с предгорными остепненными лугами и луговыми степями (29). Группы ландшафтов, расположенные на севере КМВ, обладают самым низким потенциалом, поскольку не обладают необ- 


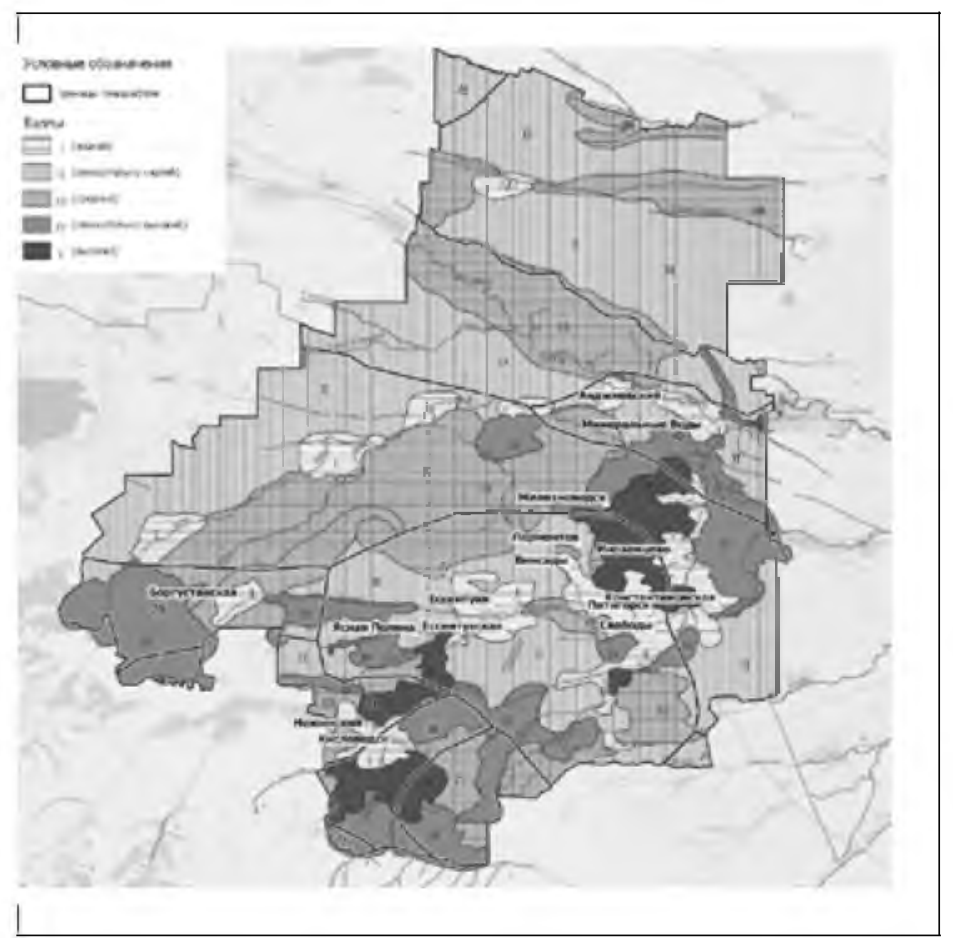

Рис. 5.

Зонирование территории для экологического туризма.

Fig. 5. Zoning of the territory for ecological tourism.

ходимым набором компонентов для привлечения рекреантов. Определяется данный факт высокой степенью антропогенной нарушенности данньх ландшафтов.

\section{Выводы}

Зонирование рекреационного потенциала на основе ландшафтного подхода и ГИС-технологий позволяет достаточно обоснованно и объективно выделять потенциальные территории для развития различных направлений туризма. Данный метод обеспечивает более детальное оценку компонентов ландшафтов, поэтому модели, созданные способом гексагональных операторов, позволяют наглядно показать ареалы с различным рекреационным потенциалом для отдельных компонентов ландшафта. 


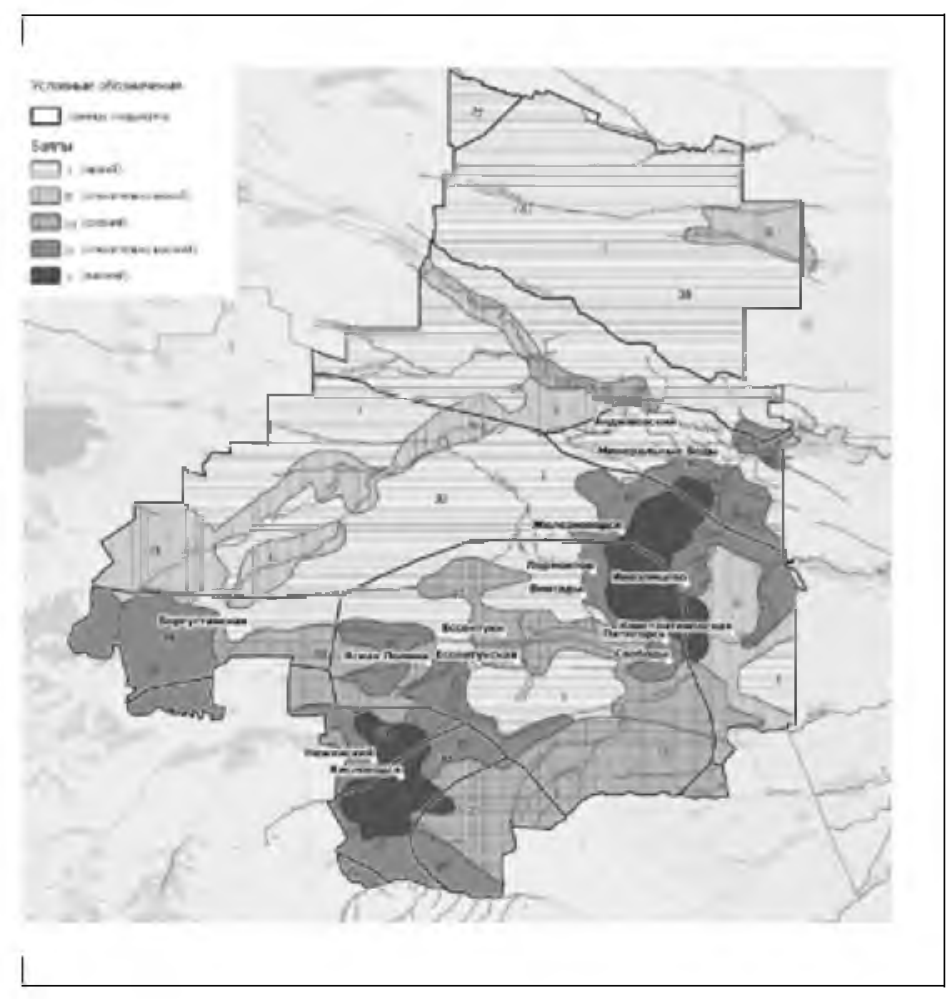

Рис. 6.

Зонирование территории для экскурсионного туризма.

Fig. 6. Zoning of the territory for excursion tourism.

В целом, по итогам интегральной оценки можно выделить несколько групп ландшафтов, которые обладают высоким потенциалом для осуществления туристской деятельности. Это ландшафты куэстовых хребтов с остепненными горными лугами и участками горных степей (21), природно-культурные ландшафты поперечных речных долин с лесостепями, остепненными лугами и горными степями (20) и ландшафты с наличием интрузивных форм новейшего вулканизма (27). В их пределах находится большое количество минеральных источников, что важно для лечебно-оздоровительного туризма. В рамках развития экологического туризма благоприятны зоны, где распространены особо охраняемые территории, имеются большие площади лесов. Экологический туризм уже сформировался и получил развитие на данной территории.

Немного уступают по ряду показателей природно-культурные ландшафты террасированных равнин и природно-культурные ландшафты аллювиальных террасированных равнин предгорий с разнотравно-злаковыми 
степями. Здесь имеются области потенциального развития, которые расположены на западе региона. Вне выделенных областей эти ландшафты не имеют высокой ценности для развития туризма. Остальные ландшафты имеют низкий потенциал, за исключением небольших участков для отдельных видов туризма.

Важно отметить, что использование ГИС-технологий дает возможность более четко выделить территории перспективного развития. Определение векторов развития туризма позволит создать конкурентоспособную среду в регионе. Полученные данные могут применяться в рамках программ устойчивого развития, использоваться при разработке документов территориального планирования, поможет инвесторам при выборе территории для туристского освоения.

\section{Библиографический список}

1. Алаев Э. Б. Социально-экономическая география: Понятийнотерминологический словарь. М., 1983.

2. Александрова Т.Д. Оценочные исследования в отечественной географии / Т.Д. Александрова, Л.В. Максимова // География и природные ресурсы. 2004. № 3. С. 28-34.

3. Арманд А.Д., Куприянова Т.П. Типы природных систем и физико-географическое районирование // Известия АН СССР. Серия географическая. 1976. № 5. С. 26-38.

4. Арманд Д.Л. Бальные шкалы в географии // Известия АН СССР. Серия геогр. 1973. № 2. С. 11-24

5. Гудковских М.В. Методика комплексной оценки туристско-рекреационного потенциала // Географический вестник (Geographical bulletin). 2017. №1(40). C. 102-116.

6. Дунец А.Н. Территориальное планирование туризма (на примере муниципальных районов Алтайского края) // Записки Усть-Каменогорского филиала Казахского географического общества. Проблемы региональной геоэкологии и природопользования. Вып. 4. Усть-Каменогорск, 2010.

7. Колбовский Е.Ю. Геоэкологические подходы к проектированию региональных туристско-рекреационных систем // Человек в зеркале современной географии. Смоленск: Изд-во СГУ, 1996 г. С. 83-85.

8. Колбовский Е.Ю., Морозова, В.В. Ландшафтное планирование и формирование региональных сетей охраняемых природных территорий. М.; Ярославль: Изд-во ЯГПУ, 2001. 152 с. 
9. Преображенский В.С. (ред.) Охрана ландшафтов. Толковый словарь. М.: Прогресс, 1982. 272 с.

10. Шальнев В.А. Ландшафты Северного Кавказа. Эволюционный подход и современное состояние. Ставрополь: Изд-во СГУ, 2007.

\section{References}

1. Alayev E. B. Social and economic geography: Conceptual and terminological dictionary. M, 1983.

2. Alexandrov T.D. Estimated researches in domestic geography / T.D. Alexandrova, L.V. Maximova // Geography and natural resources. 2004. No. 3. Page 28-34.

3. Armande A.D., Kupriyanova T.P. Types of natural systems and physiographic division into districts // News of Academy of Sciences of the USSR. Geographical series. 1976. No. 5. Page 26-38.

4. Armande D.L. Ball scales in geography // News of Academy of Sciences of the USSR. Series reorp. 1973. No. 2. Page 11-24.

5. Gudkovskikh M.V. Technique of complex assessment of tourist and recreational potential // Geographical messenger = Geographical bulletin. 2017. No. 1(40). Page 102-116.

6. A.N. tuna. Territorial planning of tourism (on the example of municipal districts of Altai Krai) // Notes of the Ust-Kamenogorsk branch of the Kazakh Geographical Society. Problems of regional geoecology and environmental management. Issue 4. Ust-Kamenogorsk, 2010.

7. Kolbovsky E.Yu. Geoecological approaches to design of regional tourist and recreational systems // People in a mirror of modern geography. Smolensk: Prod. in SGU, 1996. Page 83-85.

8. Kolbovsky E.Yu., Morozova, V.V. Landscape planning and formation of regional networks of the protected natural territories. M.; Yaroslavl: YaGPU publishing house, 2001. 152 pages.

9. Preobrazhenskiy V.S. (edition). Protection of landscapes. Explanatory dictionary. M.: Progress, 1982. 272 pages.

10. Shalnev V. A. Landscapes of the North Caucasus. Evolutionary approach and current state. Stavropol: SGU publishing house, 2007.

Рукопись поступила в редакцию 12.04.19, принята к публикации 01.06.19 


\section{6 aвторах}

Проскурин Виталий Сергеевич, ведущий аналитик ООО «Картфонд», аспирант кафедры физической географии и кадастров СевероКавказского федерального университета.

Телефон: 8-928-301-34-42.

E-mail: stavr.pro@mail.ru.

\section{About authors}

Proskurin Vitaly Sergeyevich, leading analyst of LLC Kartfond, graduate student of department of physical geography and inventories of the North Caucasian federal university.

Phone number: 8-928-301-34-42.

E-mail: stavr.pro@mail.ru 